Case report

\title{
What is Fishy in Asymptomatic Patients? Co-Occurrence of Aerococcus urinae Infection in Pediatric Patient with Phimosis
}

\author{
Gordana Smieško ${ }^{1,2}$, Pavle Banović1,3, Vera Gusman 1,2, Biljana Milosavljević2, Deana Medić1,2, \\ Tamara Bulajić, ${ }^{4,5}$, Milica Pejaković Budinskii ${ }^{2,4}$, Svetlana Golocorbin-Kon ${ }^{6}$ \\ ${ }^{1}$ University of Novi Sad, Faculty of Medicine, Department of Microbiology with Parasitology and Immunology, \\ Novi Sad, Serbia \\ 2Institute of Public Health of Vojvodina, Novi Sad, Serbia \\ ${ }^{3}$ Pasteur Institute Novi Sad, Novi Sad, Serbia \\ ${ }^{4}$ University of Novi Sad, Faculty of Medicine, Novi Sad, Serbia \\ ${ }^{5}$ Community Health Centre Novi Sad, Novi Sad, Serbia \\ ${ }^{6}$ University of Novi Sad, Faculty of Medicine, Department of Pharmacy, Novi Sad, Serbia
}

\section{SUMMARY}

Here we present the first case of Aerococcus urinae isolated from urine sample of a 5-year-old boy from Vojvodina province (Serbia). The patient had predisposing factors related to the susceptibility of genitourinary system to infection. Thus, he reported no complaints related to active urinary infections. Eradication of infection was achieved after_10-day treatment with meropenem.

From this case, the question emerges: Is there a possibility that $A$. urinae infections are neglected in pediatric patients with susceptibility of genitourinary system to infection? Only after wide introduction of matrix-assisted laser desorption/ionization time-of-flight mass spectrometry (MALDI-TOF MS) in competent laboratories, we will be able to give a precise answer.

Key words: Aerococcus urinae, urinary infection, resistance, antimicrobials 


\section{INTRODUCTION}

The genus Aerococcus was defined nearly 70 years ago with the description of Aerococcus viridans isolated from particles in dust and air (1). About 40 years later, Aerococcus urinae (A.urinae) was discovered as new species emerging pathogen isolated from human samples using 16sRNA sequencing (2). Today, genus Aerococcus consists of eight species, of which two are human pathogens $-A$. urinae and Aerococcus sanguinicola. A. urinae represent grampositive cocci with similar features to staphylococci, alpha hemolytic streptococci and enterococci (3).

With the introduction of mass-spectrometry based analysis of bacterial species, A. urinae became increasingly acknowledged as a human pathogen and identified from isolates of urine samples, blood samples, necrotic soft tissue samples, prosthetic valves and endocarditis vegetation $(2,4-6)$. A. urinae is regarded as a pathogen that is able to cause severe disease in the presence of genitourinary anomalies (7). Regardless of that, there are no previous reports of $A$. urinae isolation and determination from human samples in Serbia.

Here we report the case of $A$. urinae isolation from the urine sample of a patient admitted at community Health Centre in Novi Sad, Serbia.

\section{CASE REPORT}

The patient is a 5-year-old boy who was admitted to the community Health Centre with an elevated body temperature $\left(38.6^{\circ} \mathrm{C}\right)$ and cough. The boy was earlier diagnosed with phimosis - the condition in which the foreskin is non-retractable from the glans of the penis and was advised to locally apply $0.1 \%$ mometasone cream. Earlier, the boy's mother complained about the occasional foul smell of his urine. Regarding the current complaints, it was requested that blood and urine analysis be performed. Urine was cloudy, with numerous bacteria and noticeable proteins and leukocytes (6 per high power field). Blood analysis showed a relative elevation of lymphocytes (51.9\%; ref: $20-40 \%$ ) and eosinophils (7.2\%; ref: $0-4 \%$ ), while neutrophils showed the relative decrease (35.9\%; ref: $50-70 \%$ ); the number of leucocytes remained in physiological values $(6 \times 109 / \mathrm{L})$.

Urine sample was inoculated on blood agar, endo agar, and chromogenic agar and examined after $24 \mathrm{~h}$. Small colonies with alpha-hemolysis was an absolute indication for further examination by matrix-assisted laser desorption ionization-time of flight mass spectrometry - MALDI-TOF MS (Biotyper, Bruker, MA, USA). Using MALDI-TOF MS, we identified A. urinae in both samples.

Susceptibility of $A$. urinae isolates to antibacterial drugs was determined via the Kirby-Bauer test, a disc diffusion method. In this case, the isolated $A$. urinae was resistant against penicillin and amoxicillin (Table 1.).

Table 1. Antibiotic susceptibility $(S)$ and resistance ( $R$ ) of A. urinae isolates in the presented case

\begin{tabular}{l|c}
\hline \hline & Case 1 \\
\hline penicillin & $\mathrm{R}$ \\
\hline amoxicillin & $\mathrm{R}$ \\
\hline meropenem & $\mathrm{S}$ \\
\hline ciprofloxacin & $\mathrm{S}$ \\
\hline levofloxacin & $\mathrm{S}$ \\
\hline nitrofurantoin & $\mathrm{S}$ \\
\hline vancomycin & $\mathrm{S}$ \\
\hline rifampicin & $\mathrm{S}$ \\
\hline \hline
\end{tabular}

According to antibiogram results, meropenem i.m. was introduced for 10 days. Following the antibiotic treatment, the urine results returned to normal values and the mother reported that the foul smell of urine was no longer present. Following treatment, the urine results returned to normal values.

\section{DISCUSSION}

An interesting feature in the case presented here is that urine analysis was performed due to disease non-related to symptomatic urinary infection, since viral respiratory infection is a more probable cause for the development of chief complaints. It is known that $A$. urinae can colonize human urinary tract without causing infection, and is more likely to be isolated from urine of patients older than 65 years with underlying genitourinary tract disease $(7,8)$.

Here, the pediatric patient suffered from phimosis and a corticosteroid cream was applied locally. Thus, the symptoms related to urinary infection were not reported, and in this context, the infection can be considered as asymptomatic. Regarding the current urine findings and $A$. urinae isolation, there could be a possible link between his earlier condition 
and local treatment with corticosteroid cream. In other pediatric patients as predisposing factors were suggested bladder diverticulum (9), pelvic juxtaglomerular obstruction and kidney reflux (7), while in some cases no predisposing factors were found (10, $11)$.

There are few reports of $A$. urinae isolation from pediatric patients, all of them are boys and most of them are linked with specific urine characteristic in otherwise asymptomatic patients - foul smell of urine similar to fish odor (7, 9 - 12). In most of the reports, urine findings are similar to ours, where numerous bacteria were present as well as high levels of leukocytes $(9,12)$. In the case of the asymptomatic pediatric patient where high levels of leukocytes in urine were not found, authors suggested that isolation of $A$. urinae could be a consequence of child's bad hygiene, certain food intake, undesired loss of urine/feces or a consequence of underlying metabolic disease (11).

Implementation of MALDI-TOF MS in routine laboratories enabled precise identification of $A$. urinae in samples that were previously reported only as alpha-hemolytic streptococci. Our report of pediatric patient is consistent with previous reports from children that described $A$. urinae infection only in boys. The patient presented here was successfully treated. Thus, detected penicillin and amoxicillin resistance should be taken as a direction for the future research to determine susceptibility of $A$. urinae isolated at the territory of Vojvodina province (Serbia).

\section{Conflict of interests}

None

\section{References}

1. Rasmussen M. Aerococcus: an increasingly acknowledged human pathogen. Clin Microbiol Infect. 2016;22(1):22-7.

https://doi.org/10.1016/j.cmi.2015.09.026

2. Aguirre M, Collins MD. Phylogenetic analysis of some Aerococcus-like organisms from urinary tract infections: description of Aerococcus urinae sp. nov. J Gen Microbiol. 1992;138(2):401-5.

https://doi.org/10.1099/00221287-138-2-401

3. Rasmussen M. Aerococci and aerococcal infections. J Infect. 2013;66(6):467-74.

https://doi.org/10.1016/j.jinf.2012.12.006

4. Forsvall A, Wagenius M, Rasmussen M. Perigenital necrotizing soft tissue infection caused by Aerococcus urinae. IDCases. 2019;18.

https://doi.org/10.1016/j.idcr.2019.e00590

5. Yabes JM, Perdikis S, Graham DB, Markelz A. A rare case of Aerococcus urinae infective endocarditis in an atypically young male: case report and review of the literature. BMC Infect Dis. 2018;18. https://doi.org/10.1186/s12879-018-3414-0

6. Varughese R, Mathew A, Chadha R, et al. Prosthetic valve endocarditis caused by Aerococcus Urinae. IDCases. 2020;21:e00912. https://doi.org/10.1016/j.idcr.2020.e00912

7. Murray TS, Muldrew KL, Finkelstein R, et al. Acute Pyelonephritis Caused by Aerococcus urinae in a 12-Year-Old Boy. Pediatr Infect Dis J. 2008;27(8):760-2. https://doi.org/10.1097/INF.0b013e318170af46

8. Skalidis T, Papaparaskevas J, Konstantinou D, et al. Aerococcus urinae, a cause of cystitis with malodorous urine in a child: clinical and microbiological challenges. JMM Case Rep. 2017;4(2):e005083. https://doi.org/10.1099/jmmcr.0.005083

9. Gibb AP, Sivaraman B. A second case of foul smelling urine in a boy caused by Aerococcus urinae. Pediatr Infect Dis J. 2013;32(11):1300-1. https://doi.org/10.1097/INF.0b013e3182a64054 
10. de Vries TW, Brandenburg AH. Foul smelling urine in a 7-year-old boy caused by Aerococcus urinae. Pediatr Infect Dis J. 2012;31(12):1316-7. https://doi.org/10.1097/INF.0b013e318268d25e

11. Lenherr N, Berndt A, Ritz N, Rudin C. Aerococcus urinae: a possible reason for malodorous urine in otherwise healthy children. Eur J Pediatr. 2014;173(8):1115-7. https://doi.org/10.1007/s00431-014-2348-9

12. Sierra-Hoffman $M$, Watkins $K$, Jinadatha $C$, et al. Clinical significance of Aerococcus urinae: a retrospective review. Diagn Microbiol Infect Dis. 2005;53(4):289-92.

https://doi.org/10.1016/j.diagmicrobio.2005.06.021

\title{
Šta je sumnjivo kod asimptomatskih pacijenata? Istovremena pojava infekcije izazvane bakterijom Aerococcus urinae kod dečaka sa fimozom
}

\author{
Gordana Smieško ${ }^{1,2}$, Pavle Banović1,3, Vera Gusman ${ }^{1,2}$, Biljana Milosavljević2, Deana Medićc,2, \\ Tamara Bulajić, ${ }^{4,5}$, Milica Pejaković Budinski ${ }^{2,4}$, Svetlana Golocorbin-Kon ${ }^{6}$ \\ ${ }^{1}$ Univerzitet u Novom Sadu, Medicinski fakultet, Katedra za mikrobiologiju sa parazirologijom i imunologijom, \\ Novi Sad, Srbija \\ 2Institut za javno zdravlje Vojvodine, Novi Sad, Srbija \\ ${ }^{3}$ Pasterov zavod Novi Sad, Novi Sad, Srbija \\ ${ }^{4}$ Univerzitet u Novom Sadu, Medicinski fakultet, Novi Sad, Srbija \\ ${ }^{5}$ Dom zdravlja Novi Sad, Novi Sad, Srbija \\ ${ }^{6}$ Univerzitet u Novom Sadu, Medicinski fakultet, Katedra za farmaciju, Novi Sad, Srbija
}

\section{S A ŽETAK}

U ovom prikazu slučaja prijavljujemo prvu izolaciju Aerococcus urinae iz urina petogodišnjeg dečaka iz Autonomne Pokrajine Vojvodine. Kod pacijenta su identifikovani predisponirajući faktori za infekciju genitourinarnog sistema. Ipak, pacijent nije prijavio nikakve tegobe vezane za aktivnu urinarnu infekciju. Eradikcija A. urinae je ostvarena primenom meropenema u desetodnevnom režimu.

Nakon ovog prikaza nameće se pitanje - postoji li mogućnost da su infekcije sa A. urinae zanemarene kod pedijatrijskih pacijenata sa predisponurajućim faktorima za infekcije genitorunirarnog trakta? Precizan odgovor na to pitanje moći će da se da tek nakon sveobuhvatne implementacije MALDI-TOF MS analiza odgovarajućim mikrobiološkim laboratorijama.

Ključne reči: Aerococcus urinae, urinarna infekcija, infekcija, antibiotici 